\title{
Dios, el hombre y el mundo a la luz de la teología trinitaria actual*
}

Gerardo A. Martínez Z.**

\begin{abstract}
Resumen
el presente estudio analiza, a partir de la renovación del Tratado sobre la Trinidad, acaecido en la teología del siglo XX, las implicaciones en la concepción de Dios y el ser humano; implicaciones que tienen que ver con el redescubrir la imagen auténtica de Dios-Trinidad, su comunión intradivina y el designio divino de que el ser humano viva en esa misma comunión con Dios y con los demás. Asimismo, se profundiza de qué manera el amor trinitario, como un amor social, inspira la solidaridad y la compasión en el mundo y cómo este amor en definitiva es el modelo del amar humano.
\end{abstract}

Palabras clave: Dios, ser humano, comunión, familia, historia.

* el presente artículo está inspirado en la investigación el rostro de la familia, a partir de los desarrollos trinitarios recientes y del magisterio actual, presentada para optar al título de magíster en Teología Dogmática por la Universidad Pontificia de Salamanca (España).

** Profesor de la Facultad de Teología y del Departamento de Humanidades de la Universidad Santo Tomás. Magíster en Teología Dogmática por la Universidad Pontificia de Salamanca. Licenciado en Teología (Pontificia Universidad Javeriana). Licenciado en Filosofía y Letras (Universidad Santo Tomás). Miembro activo del grupo interinstitucional "ethikos" que investiga en el campo de la "educación moral en la educación superior" y del grupo Gustavo Gutiérrez: Teología Latinoamericana. Correo electrónico: gerardm5@hotmail.com 


\section{Lista de abreviaturas}

CCe: Cathechismus Catholicae Ecclessiae (Catecismo de la Iglesia Católica)

CDSI: Compendio de la Doctrina Social de la Iglesia

CTI: Comisión Teológica Internacional

DCe: encíclica Deus caritas est (Sobre el amor cristiano)

DCG: Directorium catechisticum generale

DV: Constitución dogmática Dei verbum sobre la divina revelación

eS: encíclica Ecclesiam suam (Sobre los caminos por los cuales la Iglesia Cató-

lica tiene hoy que cumplir su mandato)

GS: Constitución pastoral Gaudium et spes sobre la Iglesia en el mundo actual NA: Decreto Nostra aetate (Sobre la relación de la Iglesia con las religiones no cristianas)

SRS: encíclica Sollicitudo rei socialis (con ocasión del vigésimo aniversario de la Populorum progressio)

\section{Introducción}

Ante el Dios metafísico, solitario e indiferente con el ser humano, de la mayor parte del discurso filosófico, la teología no ha tenido más remedio que despertar y repensar a Dios desde su misterio más profundo: ser trinitario. La misma teología se ha conmovido a la luz de las investigaciones exegéticas y estrictamente teológicas, al situar a Dios, analógicamente, como un ser familiar y en comunión, que creó al ser humano a su imagen, para que viva también la experiencia de ser feliz con otros, en comunión y amor, es decir, creando familia.

Una de las convicciones más profundas en los desarrollos de la teología trinitaria actual es que lo que llamamos "vocación", precisamente la llamada a vivir como vive Dios: en amor y comunión. Él no es un ser solitario e indiferente, sino que la Trinidad es una comunidad viviente cuyas relaciones son un intercambio de amor. Tal es la significación profunda del misterio de la Santísima Trinidad. el Dios cristiano realiza la "familia ejemplar": es un solo Dios en tres personas (winninger, 1967). 
Profundizar entonces en el Misterio trinitario de Dios significa descubrir que el ser humano es un ser familiar, porque Dios en sí mismo es familia. el Dios cristiano no es el "Señor de los ejércitos", sino es el Dios-amor, el Dios-familia, en definitiva el Dios que nos presenta la Biblia y no la tradición filosófica. Pero aunque lo anterior sea hoy casi que evidente, no lo ha sido a lo largo de la historia de la reflexión teológica anclada y prendada de categorías exclusivamente metafísicas.

el Dios trinitario es el Dios propio del Cristianismo, y el hombre, creado a imagen y semejanza de ese Dios, se realiza en familia a ejemplo de la Trinidad, que se ha revelado en la historia como una familia.

en este escrito no pretendemos hacer un desarrollo completo de lo que ha sido la historia de la teología trinitaria (cfr. Rovira, 1993; Rovira, 2008; Ladaria, 2007). Nos interesa mostrar las grandes afirmaciones en la teología trinitaria actual que iluminan a la teología de la familia y que han permitido su desarrollo posterior. Esas afirmaciones tienen que ver con el redescubrir la imagen auténtica de Dios-Trinidad, su comunión intradivina y su designio divino de que el ser humano viva en esa misma comunión con Dios y con los demás (De Miguel, 2008). Asimismo, analizaremos de qué manera el amor trinitario como un amor social inspira la solidaridad y la compasión en el mundo.

\section{El retorno al Dios de la fe, al Dios trinitario}

el profesor salmantino Santiago del Cura (1990), en su amplia trayectoria de docente del tratado de Trinidad, explica que históricamente la reflexión filosófico-racional predominante, utilizada en la teología, terminó dejándose llevar por una dinámica y recubriendo con una conceptualidad que, en ocasiones, más bien oscurecía los rasgos propios y específicos del Dios de la revelación. Por su parte, otra autoridad teológica lo explica con estas palabras: el proceso histórico que hemos vivido es a la vez resultado de una pérdida del Dios trinitario, que tiene su reflejo en el hombre trinitariamente comprendido. El Padre u Origen, el Hijo o Verbo, el Espíritu o Amor se reflejan en el hombre que es memoria, inteligencia y voluntad. La realización humana y el acceso a lo real se tiene que realizar desde 
estos tres campos. La filosofía occidental ha absolutizado el logos y olvidado la memoria y el amor (González de Cardedal, 1997, p. 123).

De tal manera que, teniendo claro lo anterior, podemos afirmar que la teología trinitaria actual (fuente de los demás tratados teológicos) ha experimentado un viraje de pasar de "entender y explicar" a Dios in se, propio de un discurso filosófico racional, a "contemplar" su acción salvífica pro nobis en la historia ${ }^{1}$.

este cambio teológico ha puesto su acento en el Dios de la Biblia. La exégesis y la teología bíblica nos ha puesto ante un Dios al que se puede adorar (T. de Chardin) y ante el que se puede danzar y orar (Heidegger). Asistimos al descubrimiento de que el lugar natal del discurso sobre Dios es el lenguaje religioso, el lenguaje de la fe (propio de la Biblia), no el lenguaje filosófico (Greshake, 2002). Se redescubre así el misterio de la Trinidad de un Dios que es en sí mismo unidad y trinidad, cuyo lenguaje es el amor y la autocomunicación gratuita y libre hacia el ser humano (Coda, 1993).

el siglo XXI se levanta con la convicción de que "en el corazón de la fe cristiana se encuentra la confesión del Dios uno y trino y de su obra salvífica trinitaria" (Greshake, 2001, p. 31). Los tratados trinitarios actuales marcan una diferencia especial con los anteriores, porque quieren romper con la sospecha de ser una "teoría abstracta", sin relación con la vida del cristiano, que "veló el rostro de Dios"2.

en el prólogo a la edición en español de la obra de Greshake (2001, p. 7), M. Lochman afirma que la gran dificultad histórica ha sido de que el dogma de la Trinidad no se ha relacionado con la vida práctica y siempre ha estado

1 Greshake explica que desde principios de la edad Moderna se cree - ¡a lo sumo! - en un Dios representado "unilateralmente", en el "Padre celestial", en un "ser supremo" en una "Mónada" divina "suspendida y tejida" sobre todas las cosas (es decir, en un "solitario" Ser supremo último, simple, cerrado en sí mismo y autosuficiente) $(2002$, p. 8$)$.

2 es interesante el planteamiento de González de Cardedal (1997, p. 23), que al confrontarse con las causas del ateísmo se plantea que la teología tiene que preguntarse si ella no veló el rostro de Dios. y con ella toda la Iglesia tiene que preguntarse en qué medida una mala presentación teórica de Dios, de Jesucristo, una desatención a los problemas concretos de los hombres para los que el evangelio proclama salvación, una desadecuación entre lo anunciado y lo vivido, no han sido también causa del ateísmo resultante. el Vaticano II en GS 21 se ha hecho esta pregunta y dado una respuesta que invita a la autocrítica y la conversión. 
bajo sospecha de ser una teoría abstracta, por lo que plantea la tarea de desarrollar en el tratado sobre teología trinitaria los aspectos prácticos, antropológicos y ético-sociales que se infieren a partir de esta doctrina.

Por lo anterior, se abre en la teología trinitaria actual una tarea ardua, pero esperanzadora, que consiste en presentar los contenidos trinitarios como "fuente de todos los otros misterios de la fe, y ser la luz que los ilumina" (CCe 234). "Amor y comunión" son las palabras claves para acercarnos al Misterio de Dios uno y trino y para proyectar luz sobre la realidad humana, que descubre en la Trinidad su fuente y término.

Las diversas posturas trinitarias [actuales] lo que han buscado y siguen buscando es precisamente "pensar a Dios" como "amor" y "comunión"; amor y comunión en sí mismo, que en razón de la "diferencia" intradivina y personal puede crear por amor una realidad "diferente" de él para integrarla en su misma vida de reciprocidad comunional. "A esta tarea ha sido fiel la teología en la medida en que supo no sacrificar la unidad a favor de la trinidad ni la trinidad a favor de la unidad" (Del Cura, 2010, pp. 67-68).

La cuestión decisiva en el desarrollo de la teología trinitaria actual es ¿quién es este Dios que se revela? La pregunta no pretende sugerir que en el pasado esto no se haya indagado, sino que ante la nueva problemática en torno a la crítica de la religión y al ateísmo contemporáneo, la cuestión de Dios adquiere dimensiones nuevas.

Santiago del Cura (2006) observa que la presentación actual de la fe en un Dios uno y trino constituye un quehacer exigido al discurso de la teología sistemática desde diversas instancias, como el diálogo interreligioso y la cultura del pluralismo posmoderno, que tiende a proponer como evidencia incuestionable la equiparación del monoteísmo con la intolerancia y con la violencia (del Cura, 2006).

este mismo desafío de proponer el anuncio de Dios uno y trino en un tiempo marcado por una cultura posmoderna de indiferencia religiosa cada vez más extendida se encuentra en el pensamiento de w. Kasper, quien lo plantea a la luz del Concilio Vaticano II, así:

el tema que se plantea especialmente a la Iglesia y a la teología en esta situación son los presupuestos humanos de la fe (praembula fidei) y los accesos a la fe. en último término, se trata de la cuestión de Dios. La constitución pastoral Gaudium et spes ha dicho cosas esenciales y 
nuevas al respecto. en conjunto, el interés del concilio se limitó excesivamente a la Iglesia. en cambio, se dedicó poca atención al verdadero fondo y al auténtico contenido de la fe, a Dios, si establecemos la comparación con la atención que se prestó a la mediación eclesial de la fe. Principalmente en este punto, el Concilio Vaticano II plantea el desafío de ir más allá de los textos del concilio, siendo plenamente fieles a la tradición testimoniada por él, $\mathrm{y}$, a la vista del ateísmo moderno, hacer una nueva exposición del mensaje de Jesucristo, el Dios uno y trino, en su significación para la salvación del hombre y del mundo (1989, p. 114).

A partir del desafío de presentar el verdadero rostro de Dios, nos preguntamos ¿quién es este Dios que se revela? el Dios revelado es un Dios Trinidad, que por gracia y libertad ha querido revelarse en la historia humana. La revelación bíblica es testimonio de este acontecer de Dios en la historia, que tiene su plenitud en la encarnación de Dios por Jesucristo en el espíritu Santo. esta verdad de fe la expresa bellamente el Catecismo de la Iglesia Católi$c a$, aludiendo al DCG 47, con estas palabras: “Toda la historia de la Salvación no es otra cosa que la historia del camino y los medios por los cuales el Dios verdadero y único, Padre, Hijo y Espíritu Santo, se revela, reconcilia consigo a los hombres, apartados por el pecado, y se une con ellos" (CCe 234).

Dios excelso, infinitamente superior a todo pensamiento e imaginación humanos, se nos ha revelado y comunicado en libertad. Solo desde sí puede Dios revelarse; únicamente Él mismo puede decir quién es, y lo ha hecho. Ya la creación es un modo de esa autorrevelación de Dios, como se expresa en Rom 1,20: "Lo invisible de Dios, desde la creación del mundo, se deja ver a la inteligencia a través de sus obras: su poder y su divinidad" (como se cita en Greshake, 2002, p. 13).

\section{La revelación de Dios en la historia}

La constitución conciliar Dei Verbum (núm. 4) sobre la divina revelación es clara en afirmar el carácter histórico de la revelación de Dios por Jesucristo en el espíritu. "Después que Dios habló muchas veces y de muchas maneras 
por los profetas, últimamente, en estos días, nos habló por su Hijo" (Heb 1,1-2), pues envió a su Hijo, es decir, al Verbo eterno, que ilumina a todos los hombres, para que viviera entre ellos y manifestara los secretos de Dios (Jn 1,1-18)".

Según lo anterior, el Concilio, en los cuatro primeros números de la Dei Verbum supone, como afirma Pikaza, que la Trinidad en sí (inmanencia divina) se revela y manifiesta en la economía de la salvación, de tal forma que todo el camino de la historia y, en general, de la vida cristiana, es una experiencia trinitaria (Pikaza, 2005, p. 239).

Precisamente en el despertar de la teología trinitaria, la relación Trinidad e historia ha tenido nuevos desarrollos. en esta línea, los trabajos de M. Bruno Forte son de especial atención. en su libro Trinidad como historia (1996), explica que la tesis de correspondencia entre la Trinidad económica y la Trinidad inmanente de Karl Rahner no está exenta de limitaciones y de riesgos, ya que esa correspondencia no puede concebirse como identidad.

Forte llama la atención, recordando que ya Tertuliano hacía la distinción entre economía e inmanencia en el misterio trinitario y esto le parece conveniente porque la economía no puede agotar la profundidad de Dios ni la historia puede capturar su gloria. Según el autor, la revelación de Dios en libertad divina brota de una voluntad distinta y soberana, totalmente libre y no necesitada. La iniciativa divina de la Salvación es motivada solo por la gratuidad del amor.

Un Dios resuelto en la historia. Una Trinidad divina inmanente adecuada por completo a su revelación económica, no sería ya el Dios cristiano, sino una entre tantas fuerzas de este mundo, quizá la más alta y necesaria. La trascendencia y la ulteridad del Dios en sí respecto al Deus pro nobis se dejan captar en una doble dirección: por una parte, en el sentido de la apófasis, de la inefabilidad del misterio divino totalmente otro, aunque se haya realizado totalmente dentro de las vicisitudes humanas; por otra, en el sentido de la escatología, de lo venidero y lo nuevo, propio del Dios cristiano como Dios de la promesa (Forte, 1996, p. 23).

Sobre la tesis de Rahner (1969): “[...] la Trinidad económica es la Trinidad inmanente y viceversa". Forte puntualiza que a esta tesis le corresponde 
una obligada antítesis (CTI, 1981): "la Trinidad inmanente no es la Trinidad económica", ya que esperamos la síntesis escatológica cuando "Dios sea todo en todos" (1 Cor 15,28), cuando la historia y la gloria vivan en una diversidad plenamente reconciliada: “Frente a este 'todavía no' de la promesa, frente a esta última patria 'vislumbrada, pero no poseída', el teólogo sabe que está pensando en las sombras del atardecer: como el centinela espera la aurora (cf. Sal 130,6)" (Forte, 1996, p. 25).

Sin embargo, guardando la debida tensión en el discurso sobre Dios, al cual nos acercamos "entre sombras", Forte afirma que no se nos ha dado otro lugar a partir del cual sea posible hablar con menor infidelidad del misterio divino que la historia de la revelación, es decir, en los acontecimientos y las palabras íntimamente unidos, por los que Dios ha narrado en nuestra historia su propia historia (su "economía", como la llamaban los Padres, la "dispensación" del don de arriba que nos salva). La Trinidad tal como es en sí ("inmanente"), concluye Forte, se da a conocer en la Trinidad tal como es para nosotros ("económica")" (1996, p. 20).

\section{Un Dios uno y trino en comunión de personas en el amor}

en la obra clásica de Teología Dogmática de J. Auer y J. Ratzinger (1982), al acercarse al Misterio trinitario, hay una afirmación fundamental: en definitiva el misterio último de Dios, de su ser uno y trino, del acercamiento de la razón humana para hablar de tal misterio, es el misterio de su amor: Dios es trinidad porque es amor y es amor porque es Trinidad.

Según estos autores, los conceptos utilizados para acercarse al misterio trinitario como comunión, relación, unidad, están dentro de la lógica del Dios uno y trino en relación con su agape. Dentro de este esquema, se comprende la afirmación de San Agustín: "[...] ves la Trinidad si ves el amor" (s. Agustín, De Trinitate VIII, 8, 12).

Visto esto podemos afirmar que el amor intratrinitario es amor de comunión, es decir, comprender tal amor es comprender a su vez la comunión intradivina. La comprensión de Dios trinidad pasa entonces por la comprensión de su amor, de su ágape (Coda, 1996). 
el discurso de Dios uno y trino que no se acerque a la cuestión de qué es el amor en Dios y de cómo Dios ama, como horizonte para la comprensión del amor humano, es un discurso que más que aclarar el misterio de Dios lo oscurece en formas incomprensibles, como ha sucedido a lo largo de la historia de la exposición del pensamiento trinitario.

el desarrollo teológico de la doctrina trinitaria dedujo las procesiones y relaciones intratrinitarias a partir de las misiones visibles del Hijo y del Espíritu a nuestra historia; así, esos mismos envíos del Hijo y del Espíritu Santo son la expresión última de un amor radical en Dios, concluyéndose que Dios es personalmente amor en su ser más íntimo (Auer, 1982, p. 590).

Auer explica que el pensamiento trinitario y su vinculación al agape de Dios está expresado especialmente en Ricardo de San Víctor ${ }^{3}$ para quien creación, redención y santificación son obras del amor de Dios, amor que, a su vez, no es sino la misma vida intratrinitaria. el Padre es amor, y por amor engendra en el conocimiento de sí mismo al Hijo, para poder amarle como a un tú esencialmente igual a él con un amor a su vez, que es el espíritu Santo como persona:

Humanamente hablando, generación y procesión son en Dios expresión del ser divino del amor. Las misiones del Hijo y del Espíritu en este mundo son prolongación de esa generación y espiración hasta nuestro mundo humano, que a su vez ha sido creado por el amor de Dios. en este mundo Dios se ha creado con el hombre una imagen, en la que ha entrado de manera singularísima con la encarnación de Cristo, $y$ en la que quiere ligarse en el tiempo terrestre y para siem- pre mediante la inhabitación del espíritu Santo y del Dios trino (Auer, 1982, p. 590).

en la encarnación de Cristo, Dios se nos ha acercado tanto que se ha hecho posible para nosotros los hombres la afirmación de que Dios es amor. en esta línea, recordemos la intuición de esta revelación del amor de Dios en Cristo en el pensamiento de Balthasar:

3 Para un estudio sistemático de Ricardo de san Víctor, ver Ladaria (2002). 
en la kénosis de Cristo (y sólo en ella) aparece el íntimo misterio del amor de Dios, que en sí mismo es amor $(1 \mathrm{Jn} 4,8)$ y por esta razón "trinitario". La Trinidad de Dios, siendo una luz inaccesible a la razón, es la única hipótesis cuya aplicación permite aclarar de una manera correcta desde el punto de vista fenomenológico el fenómeno de Cristo (tal como sin cesar se hace presente en la Biblia, en la Iglesia y en la historia) (2004, pp. 82-83).

este pensamiento de Balthasar coincide con otros autores que observan que la expresión Dios es amor es fundamental para acercarse al Misterio de Dios:

Toda la plenitud del ser que es característica de la esencia divina, y que el Nuevo Testamento, en especial los escritos de Juan, expresa en los simbolismos de la luz, la vida, el espíritu, reciben su sentido definitivo y más profundo a partir de 1 Jn 4, 8.16" (Ladaria, 2002, pp. 126-127).

en el amplio estudio de C. Spicq (1977) sobre el agape de Dios, presenta un dato importante: la comprensión nueva de Dios y su amor que se abre en Jesucristo, la encontramos en el Nuevo Testamento, especialmente en los escritos de Juan, desde dos textos fundamentales, que nos revelan el rostro de Dios en Jesucristo: Jn 3,16 y 1 Jn 4, 8-16.

Sobre el primer texto de Jn 3,16 ("Porque tanto amó Dios al mundo que dio a su Hijo único, para que todo el que crea en él no perezca, sino que tenga vida eterna") dirá Spicq (1977) que, con toda justicia, se considera este versículo como el resumen del evangelio de Juan, y explicará el verbo como la palabra clave de toda la Revelación, es decir, del misterio de Dios, de la cristología y la soteriología.

en efecto, es el amor quien establece vínculo entre Dios y los hombres, entre la eternidad y la historia (Jn 3,12: "Si al deciros cosas de la tierra, no creéis, ¿cómo vais a creer si os digo cosas del cielo?"). y en Cristo es como el creyente accede al conocimiento de Dios (Spicq, 1977, p. 1028).

Dirá también Spicq (1977) que ningún texto de la Sagrada escritura ofrece más luz sobre la "caridad", porque en él se revela: 
- que este amor es un atributo del Padre, que es eterno, puesto que es anterior al envío de su Hijo, e inspira el plan de la salud;

- universal, puesto que se extiende al mundo entero;

- perfectamente gratuito, sin otro motivo que Él mismo;

- no solamente es todo benevolencia y misericordia, sino también activo y dinámico; donde Él mismo toma la iniciativa y quiere probarse;

- lo que se revela sobre todo es una inmensidad. Con toda seguridad, lo que el apóstol San Juan quiere sugerir a sus lectores es la infinitud del agape divino.

Y sobre el segundo texto, que es el centro de nuestra reflexión (1 Jn 4,8), Spicq (1977) afirma que el "Amémonos unos a otros" de San Juan no es un deber arbitrario ni la simple fidelidad a un mandamiento ni siquiera un "espíritu"; es una exigencia natural de las cosas: Dios es amor. este texto Spicq lo titula El ejercicio de la caridad fraterna, como don divino, implica ser engendrado por Dios y permanecer en comunión con él y lo explica con estas palabras:

[Dios] ha engendrado a los cristianos comunicándoles su propia naturaleza y su vida; desde ese momento sus hijos son capaces de amar como su Padre celestial. La caridad del discípulo es, por consiguiente, la puesta en obra y la prueba de su filiación. Esta concepción tan límpida como profunda es la suprema revelación del ágape neotestamentario (1977, p. 1207).

La lógica que se desprende del análisis de 1 Jn 4,7-8 es que nosotros debemos amarnos porque el amor procede de Dios. Dicho de otra forma, todo el que ama es engendrado por Dios, se parece a Dios porque Dios es amor. en esta misma línea, Piero Coda concluirá: “'Dios es amor' es por tanto solo verdaderamente una frase humana si Dios, en cuanto amor, es un acontecimiento entre los hombres: "si nos amamos mutuamente, Dios está con nosotros y su amor está realizado entre nosotros" (cf. 1 Jn 4,12)" (1996, p. 66).

el agape no solo está conectado con su principio, sino (en sí) es considerada en su acepción formal y a la vez universal: el amor al prójimo y el amor a Dios son de la misma naturaleza. Si se llama al cristiano "el que ama" es porque se caracteriza por una manera de amar, por una especie de amor 
muy particular, de especie divina, y porque debido a ello recibe una denominación original entre todos los afectos, benevolencias: el ágape, de origen celestial (Spicq, 1977, págs. 1207-1208).

en síntesis, para Spicq (1977), el agape no es un don divino entre tantos, una gracia particular o un carisma, es el don por excelencia propio de la filiación divina; hemos recibido la capacidad de amar, un poder de dilección inherente a la naturaleza divina de que se ha hecho partícipe. el mandamiento de amar al prójimo se comprende como amar al prójimo como Dios me ama y como Dios lo ama. A la manera de Dios, al estilo de Dios.

Se ama precisamente por el hecho de ser engendrado por Dios y esto hemos de entenderlo en su sentido más realista. el fundamento del mandato de la caridad fraterna: amar a los otros; no por razón de conveniencia moral o de una perfección ideal, sino como el movimiento vital que emana de la nueva naturaleza [recibida del bautismo]. el ágape es el fruto de esta "semilla" divina recibida en el bautismo (Spicq, 1977, pp. 1208-1209).

en 2005, con la publicación de la primera encíclica Deus Caritas est de Benedicto XVI, la verdad central del cristianismo, Dios es amor, se puso de relieve como una verdad existencial, respuesta al desamor con el que vive la cultura actual. Unos meses antes de la aparición de la encíclica, pronunció unas palabras en las que conectaba esta verdad con el Misterio trinitario de Dios:

Toda la revelación se resume en estas palabras: "Dios es amor" (1 Jn 4,8-16); y el amor es siempre un misterio [...] Jesús nos ha revelado el misterio de Dios: el Hijo nos ha dado a conocer al Padre que está en los cielos, y nos ha donado el Espíritu Santo, el Amor del Padre y del Hijo. La teología cristiana sintetiza la verdad sobre Dios con esta expresión: una única sustancia en tres personas. Dios no es soledad, sino comunión perfecta. Por eso la persona humana, imagen de Dios, se realiza en el amor, que es don sincero de sí (Benedicto XVI, 2005).

Nos interesa mostrar qué imagen del ser humano se desprende de esta verdad que hemos expuesto sobre Dios amor-comunión, como desarrollo 
fundamental de la teología trinitaria actual. el concepto de persona ${ }^{4}$ que se desprende de esta verdad fundamental nos ayudará para comprender la profundidad que se encuentra al considerar a la familia como "comunidad de personas en el amor".

\section{El ser humano como un ser creado para la comunión y el amor}

Desde la identidad trinitaria de Dios, el ser humano adquiere su verdad plena. Si Dios es amor y comunión intradivina, el hombre creado a su imagen y semejanza es también un ser para el amor y la comunión. esta verdad está en el centro de la antropología cristiana ${ }^{5}$, quien a través de la doctrina de la imago dei presenta las consecuencias que tiene para el ser humano el ser consciente de su condición de criatura de Dios y de filiación divina, tal como se reconoce en la revelación bíblica (cf. Gen 1,26s; 5,1-3; 9,6).

el Concilio en GS 12 y 22, al referirse a la dignidad de la persona humana, funda el respeto al ser humano precisamente en esta verdad revelada del hombre como creación divina (CCe 356-361), la cual indica la vocación del hombre: es y está llamado a ser imagen de Dios, un ser personal y social, relacional, fiel, llamado a asociarse y vivir en y entre comunidad de personas, siendo la primera la compuesta por un hombre y una mujer (Ruiz de la Peña, 1988, pp. 185-186).

La Iglesia anuncia esta verdad sobre el hombre que excluye toda discriminación, ya que en el ser "imagen de Dios" se fundamenta la fraternidad universal (NA, núm. 5) y el principio de la libertad humana. en el hombre está la decisión de buscar a su Creador y llegar libremente a la plena y feliz perfección por la adhesión a él y para esto debe pedir la ayuda de la gracia divina (GS, núm. 17).

4 Para el estudio de la importancia que tiene el concepto de persona, de su dignidad, a la luz de la verdad de Dios, ver: Flecha, J. R. (2005). Moral de la sexualidad. La vida en el amor. Salamanca: pp. 19-42. (2005). Moral fundamental. La vida según el Espíritu, Salamanca: pp. 145-161.

5 Ver el estudio de Ruiz de la Peña (1988, pp. 78-81) y Greshake (2002, pp. 39-44). 
Recientemente, la Comisión Teológica Internacional se pronunció al respecto sobre la doctrina de la imago Dei, recordando la riqueza de esta verdad y su correcta interpretación, en la que se juega la comprensión bíblica de la naturaleza humana y de las afirmaciones de la antropología bíblica en el Antiguo y Nuevo Testamento.

A pesar de que esta verdad ha sido puesta en discusión por algunos pensadores modernos influyentes, hoy los teólogos y los biblistas están de acuerdo con el Magisterio en volver a descubrir y afirmar la doctrina de la imago Dei [...] Para la Biblia, la imago Dei constituye casi una definición del hombre: el misterio del hombre no se puede comprender separado del misterio de Dios (CTI, 2004, p. 17).

en este orden de ideas, es muy importante la pregunta que se hace J. García Rojo (2007) al comentar la encíclica Deus caritas est: "Si Dios es amor, ¿qué es el hombre?". Para responder esta pregunta el autor expresa que lo primero que hay que aclarar es de qué tipo de amor estamos hablando y se responde que es el amor que se ha manifestado en la creación, en la historia del pueblo de Israel y, sobre todo, en la entrega de Jesucristo en la cruz por amor, retomando lo dicho por el papa Benedicto XVI: "Dios ama tanto al hombre que, haciéndose hombre él mismo, lo acompaña incluso en la muerte y, de este modo, reconcilia la justicia y el amor" (DCe, núm. 10).

Se hace referencia a un tipo de amor concreto, el amor de Dios, el amor con el cual Dios nos ama. Después de presentar la novedad de Dios y de Jesucristo "amor de Dios hecho carne", y relacionarlo con la crisis de los humanismos en la era tecnológica, que más que humanizar han deshumanizado al hombre, J. García, a la luz de la encíclica, muestra que la respuesta a la pregunta: si Dios es amor, ¿qué es el hombre? ahonda en la novedad de la revelación bíblica con respecto al hombre, esto es, el hombre ha sido creado a imagen y semejanza de Dios, que es amor (García Rojo, 2007).

Según lo anterior, la respuesta viene dada al relacionar dos verdades intrínsecas al cristianismo: que el hombre es creado a imagen de Dios (Gn 1,26-27) y que este Dios es amor (cf. 1 Jn 4,8) y se ha revelado definitivamente en Jesucristo (Jn 3,16). J. Martín Velasco tiene unas líneas de inmensa belleza en las que relaciona el encuentro con Dios en Jesucristo y su humanidad: 
el cristiano que hace suya la vida de Jesús y en él se encuentra con Dios, asumirá desde ese encuentro su existencia con un estilo peculiar que da lugar a la "vida cristiana" [...] ese estilo de vida baña toda la existencia en el clima de la confianza y la libertad interior [...] esta vida manifiesta el encuentro con Dios que es amor en el amor efectivo por los hermanos. Con este realismo se expresa en el cristianismo la relación religiosa. y todo tiene su centro en la convicción fundamental, en la vivencia de que en Jesucristo el hombre se ha encontrado en relación viva y personal con el Dios vivo (2007, p. 56).

La teología trinitaria actual ha retomado esta verdad del misterio trinitario de Dios en relación con el hombre y expresa las consecuencias en el misterio del hombre a la luz del misterio de Dios, entendiendo que la revelación de quién es Dios va de la mano de la revelación de quién es el hombre; en otras palabras, conocer a Dios es conocer también a su creatura. La fe cristiana desde el misterio trinitario se presenta, entonces, como un horizonte de experiencia integrador de toda la realidad. "Donde Dios habla y actúa, no afirma solamente algo sobre sí mismo, sino también sobre el destinatario de su hablar y actuar: sobre el hombre y su mundo" ( Greshake, 2001, p. 48).

Si Dios es comunidad de vida y amor, esto "debe" tener, por decirlo así, consecuencias para el hombre. Greshake ${ }^{6}$ lo dirá con estas palabras: “[...] solo desde la mirada a Dios se hace reconocible con máxima profundidad qué es lo que reproduce exactamente la criatura dotada de espíritu y a qué remite con precisión su condición de imagen de Dios" (2002, p. 11).

en este sentido, S. del Cura (2010) expresa que ante el ateísmo reinante y las deformaciones de la imagen de Dios y del hombre que conlleva el ateísmo y la increencia hay que retomar y expresar nuevamente la verdad sobre Dios Trinidad y sobre el hombre imagen de este Dios Trinidad-amor-comunión.

6 el autor analiza que el desvelamiento del rostro de Dios y de su amor va acompañado del desvelamiento de quién es el hombre: "[...] en la medida en que Dios, como confiesa el creyente, sale de sí mismo y se comunica al hombre en su mundo y en su historia, no sólo se pone de manifiesto quién es Dios, sino también quién es el hombre". 
La comprensión de todo ser humano como imagen de Dios constituye un núcleo central de la antropología cristiana. Ha gozado de predilección a lo largo de los siglos [...] en nuestros días sigue siendo invocada reiteradamente [...] para describir la verdadera naturaleza del hombre y fundar en ella la dignidad de todos y cada uno. La teología contemporánea le otorga una atención preferente y retiene que es una categoría apta para el diálogo con otras antropologías, siendo válida también en las condiciones propias de una sociedad globalizada. Es, finalmente, una categoría cargada de profundo dinamismo entre lo que ya se es y lo que se llegará a ser (Del Cura, 2010, p. 167).

Precisamente Benedicto XVI en Deus caritas est se plantea la pregunta de si es posible amar como Dios ama. el Papa afirmaba que Dios nos ha mostrado su amor: se ha hecho presente entre nosotros, visible en Jesús plenamente, en la historia de amor del pueblo de Israel. Se ha quedado en la eucaristía, en la historia de la Iglesia, en sus apóstoles. A través de los hombres en los que Él se refleja, en su palabra, en los sacramentos; en la liturgia de la Iglesia, en su oración, en la comunidad viva de los creyentes:

Dios nos ha amado primero y sigue amándonos primero; por eso, nosotros podemos corresponder también con el amor [...] Él nos ama y nos hace ver y experimentar su amor, y de este "antes" de Dios puede nacer también en nosotros el amor como respuesta (DCE 17).

En definitiva, podemos amar como Dios ama porque él se ha quedado con el ser humano, nos acompaña, nos ha amado primero y al ser creados a su imagen y semejanza fuimos creados para la comunión y el amor.

quisiéramos terminar este apartado con las palabras de H. de Lubac, que nos introducirán al siguiente, en las que intuye que en la revelación del Dios uno y trino y en su agape encontramos la verdad y el designio sobre el ser humano, creado no en solitario, sino para ser con el otro, en comunidad. el hombre está llamado a estar en comunión con Dios y con los demás, y esta llamada forma parte de su ser más profundo.

Nada de lo que el hombre crea o de lo que se desenvuelve en un plano puramente humano puede arrancar al hombre de su soledad. esta se irá ahondando en la misma medida que el hombre se descubre a sí 
mismo. Porque ella no es otra cosa que el reverso de la comunión a la que él está llamado [...] Dios no nos ha creado "para seguir en los términos de la naturaleza" ni para cumplir un destino solitario. Nos ha creado para ser introducidos juntos en el seno de su Vida trinitaria [...] Ahora bien, hay un lugar, aquí abajo, en el que comienza esta reunión de todos en la Trinidad. Hay una "familia de Dios", misteriosa extensión de la Trinidad en el tiempo, que no solo nos prepara a esta vida unitiva y nos proporciona la firme garantía de poseerla, sino que nos hace participar ya de ella. es la única sociedad plenamente "abierta", es la única que se ajusta a la medida de nuestro deseo íntimo y en la que nosotros podemos alcanzar finalmente todas nuestras dimensiones[... ] así es la Iglesia. ella está llena de la Trinidad (1980, p. 260).

es decir, ser "creado a imagen y semejanza de Dios" implica estar en comunión no solo con Dios, sino también con los hermanos. Aquí aparece la dimensión social del ser humano que tiene su modelo y origen en el "nosotros divino" de la Trinidad ${ }^{7}$. Abriéndose el horizonte para profundizar en la dimensión social de la Trinidad como fuente de toda comunidad humana.

esta conciencia de mutua relación entre la Trinidad y el mundo, la historia y la sociedad, en la evolución de los estudios trinitarios y en el pensamiento eclesial, es más patente. Hay un reconocimiento generalizado de que la Trinidad de Dios es modelo para toda comunidad humana, desde la familia a la Iglesia. el padre R. Cantalamessa, en un comentario a las lecturas de la solemnidad de la Santísima Trinidad, lo expresaba con claridad y vehemencia:

La Trinidad es el modelo de toda comunidad humana, desde la más sencilla y elemental, que es la familia, a la Iglesia universal. Muestra cómo el amor crea la unidad en la diversidad: unidad de intenciones,

7 Ver el comentario que hace N. Silanes, al texto de Gn 1,26. el autor dirá que dentro de una concepción histórico-salvífica, hay que entender que este texto entraña en "embrión" toda la teología de la familia y de la Comunidad de la Iglesia, que aparece en el Nuevo Testamento como Pueblo de Dios, Cuerpo de Cristo y Templo del espíritu Santo, en el que todos los hombres, hijos en el Hijo, podrán vivir la comunión del mismo Espíritu, que los constituye hijos de Dios y hermanos (1991, pp. 24-25). 
de pensamiento, de voluntad; diversidad de sujetos, de características y, en el ámbito humano, de sexo (2005).

La Trinidad, entonces, como modelo de la comunidad humana, se plantea no en abstracto, sino en su relación con la sociedad y sus implicaciones en el ámbito eclesial y familiar, ya que Iglesia y familia son comunidades sociales llamadas a colaborar en el desarrollo social, teniendo como fuente e inspiración la dimensión social de la Trinidad.

\section{Amor trinitario: amor social. La dimensión social de la Trinidad}

este título hace referencia al planteamiento sobre la legitimidad por la pregunta de si es posible iluminar desde la Trinidad un modelo social o programa social. Si como hemos afirmado que la "Trinidad es el Misterio central de la fe y la vida cristiana", tal misterio, que es comunidad, familia, comunión, inspira a la familia humana y sus anhelos de vivir en paz, comunión y amor.

Pero algo que podría ser evidente no lo ha sido, debido al "extrañamiento en la teología de la Trinidad" ${ }^{\prime}$, a la que ya nos hemos referido. La comprensión no trinitaria de Dios, sino "monárquica" y "autoritaria", ha dejado en la historia heridas abiertas que han alejado el discurso sobre Dios del campo social y político por sospechas de querer implantar teocracias, ideologías, idolatrías, patriarcados políticos, poderes sin control sostenidos en nombre de Dios.

La doctrina de la Trinidad, que tiene su origen en el testimonio neotestamentario de la historia trinitaria del Hijo y en la praxis eclesial del bautismo en el nombre del Dios trino, según Moltmann (1986) fue adquiriendo forma y formulación mediante adaptaciones teológicas de conceptos filosóficos en

8 Greshake (2001, p. 39) se refiere a este extrañamiento trinitario también en la conciencia social. "Si Dios es comunicación, vida entregada, reciprocidad, agape eterno y todo aquello que significa su ser trino, esta imagen de Dios, tendría que transformar no solo la imagen humana de Dios, sino que también nuestra comprensión de nosotros mismos y del mundo". 
la lucha contra las herejías que cuestionaban la unidad de Cristo con Dios9. este autor planteaba la necesidad de retomar una comprensión trinitaria de Dios que fundara las relaciones con el hombre mismo, con el mundo y la sociedad y que no fuera "una especulación para teólogos, que nada tiene que ver con la realidad" y propone la "vuelta al pensamiento trinitario".

Por su parte, Vásquez (2008), en la misma línea de Moltmann, señala que a lo largo de la historia lo que se ha hecho es una descripción formal de la "vida interior" de Dios, en vez de una exposición del reino de Dios en relación con los hombres y el mundo. La idea de monarquía ${ }^{10}$ (Dios uno y único) se convirtió en una noción teológica con peligro de distorsión ideológica y confundible con la promoción de una forma de vida contraria a la vida de Dios.

El retorno al cauce trinitario supone una purificación del concepto de Dios y de las distorsiones sobre la comprensión trinitaria que llevaron a una praxis política y de relación con el mundo desde el poder y la opresión. el punto de partida es el pensamiento relacional y comunitario de la doctrina trinitaria que se aplicará a las relaciones del hombre con Dios, con los otros, con la humanidad y con toda la creación [...] esto dará lugar a una reelaboración de la doctrina sobre la trinidad y obligará a crear y a ejercitar el pensamiento trinitario" (Moltmann, 1986, p. 33).

el pensamiento trinitario puede superar el monoteísmo riguroso que lleva consigo la teocracia, como demuestra el caso del islamismo. y en el caso de la fe cristiana, un monoteísmo cerrado en la que la propia fe en Cristo corre peligro, ya que, desde aquel, Cristo debe retirarse para ingresar en la serie de profetas o desaparecer en el Dios uno como una de sus versiones,

9 Moltmann (1986) explica que la lucha contra el arrianismo, de una parte, y la ardua superación del sabelianismo, de otra, contribuyeron a la elaboración explícita de la doctrina de la Trinidad y agrega que al ser estas herejías de naturaleza cristológica el dogma sobre la Trinidad nace de la cristología, desde la auténtica fe en Cristo, Hijo de Dios, en cuya esperanza se orienta hacia la salvación alcanzada plenamente en la comunión con Dios. Herejías que no pertenecen solo al pasado, sino que son peligros permanentes. Moltmann además agrega que el gran aporte teológico de la iglesia antigua fue la recepción de la idea monoteísta y monárquica de Dios y su superación trinitaria, no solo en el plano doctrinal, sino también en el de la teología política.

10 Ver el estudio de Uríbarri (1996) sobre el "monarquianismo" y su vinculación cristiana al referirse a la noción de "monarquía divina" en los Padres de la Iglesia. 
y concebir a Dios sin Cristo y, en consecuencia, entender a Cristo sin Dios (Moltmann, 1986, pp. 147-148).

el planteamiento de Moltmann acerca de una doctrina social de la Trinidad, como teología de la experiencia social de Dios, abrió el horizonte para desarrollar en el campo de la teología trinitaria la mirada hacia la "trinidad como la mejor comunidad" (Boff, 1987; Boff, 1990), como "modelo social" (Cambón, 2000) o "programa social del cristianismo" (Silanes, 1991), ya que su visión teológica trinitaria se plantea como una "doctrina salvífica y social de la trinidad" (Moltmann, 1986, p. 173).

Según N. Silanes, el tema de la "Trinidad como programa social" es relativamente reciente en la teología católica y protestante, teniendo como precursores a J. Moltmann, N. Fedorov, P. Evdokimov, B. Forte, L. Boff y X. Pikaza, entre otros. "en estos autores lo que se ve es el esfuerzo de explicar cómo la Santísima Trinidad, que es una familia en comunión, 'comunidad original', es el paradigma de toda comunidad humana" (Silanes, 1991, pp. 8-19).

Comunidad que, según explica Greshake, es "vida en comunión", entendiendo communio no como un concepto estático, sino como acontecimiento, en un proceso en el que cada uno de los diferentes elementos encuentra unidad precisamente en su diferencia al permitir a los demás participar en su vida, haciendo realidad una vida común. Communio, añadirá este pensador, "es la mediación de identidad y diferencia: de una distinción que es conforme a la unidad, de una unidad que se realiza precisamente en el concierto de los muchos"' (2002, p. 28).

El mismo Greshake, comenta la afirmación de Gregorio Nacianceno así:

[...] la vida de Dios es en cierto modo un 'latido' conforme al cual de la unidad se hace Trinidad, y de la Trinidad, a su vez, unidad", dirá que esta conciencia trinitaria presente ya en los teólogos capadocios del siglo IV se formula con el término teológico Pericoresis que significa 'danzar alrededor', es decir, el uno danza alrededor del otro, el otro danza alrededor del uno: el Hijo está totalmente en el Padre y con el Padre; el Padre, totalmente en el Hijo y con el Hijo; y ambos encuentran su unidad mediante el vínculo del espíritu. Así danzan la única danza común de la vida divina (2002, p. 29). 
este pensamiento de la Trinidad como familia en comunión abrió el horizonte para pensar a Dios como un ser no en solitario, sino en compañía (el Padre en comunión con su Hijo y el Espíritu Santo) y para leer la revelación bíblica en clave familiar. en la presentación del XXIX Simposio de Teología Trinitaria, celebrado en Salamanca el año 1995, Silanes acertadamente afirmó:

La Trinidad es una familia que busca al hombre para incorporarlo a ella misma y ¿cómo sucede esa incorporación?: el hombre, en Cristo, es hijo del Padre, hermano del mismo Cristo, que viene a ser el Primogénito entre muchos hermanos y queda bajo el área del espíritu y animado por Él, que actúa como "espíritu", es decir, como "principio de vida familiar": amor, comunión y don, al Padre, por Cristo y en Cristo, y a los hombres, por Cristo y en Cristo, desde el Padre. el Concilio mismo llega a calificar al Espíritu Santo como “Espíritu familiar” (1995, p. 10).

Lo anterior resume la perspectiva del pensamiento de Silanes, quien ya en su discurso de ingreso en la Real Academia de Doctores, en 1991, había expuesto los fundamentos bíblicos y teológicos de la afirmación "Dios es familia", "Dios es comunión". Para este autor, el proyecto del Padre sobre el hombre no ha sido otro que asociar a todos los hombres a la comunión trinitaria, constituyéndolos hijos suyos en el Hijo encarnado, a quien ha predestinado como "primogénito entre muchos hermanos" (cf. Rom 8,29), unidos todos en el mismo Espíritu de comunión que une al Padre y al Hijo, y llamados todos a vivir con las tres Personas en el "hogar cálido y entrañable del Padre" (cf. Jn 14,2). este es el "misterio" escondido en los siglos a las generaciones pasadas (cf. Col 1,26), revelado en Cristo: "Cristo en vosotros" (cf. Col 1,27) (Silanes, 1991, pp. 19-20).

La expresión "hogar cálido y entrañable del Padre", según Silanes (1991), en referencia a la cita de Jn 14,2 y ss ("en la casa de mi Padre hay muchas mansiones[...]"), es utilizada por el evangelista para expresar la realidad del ser divino como misterio de comunión, regazo en el que se da la relación interpersonal, de amor, confianza, intimidad, compenetración y vida de familia, de intercomunión e intercompenetración.

esta vida de familia en el "hogar cálido de la Trinidad" pone de manifiesto la importancia de Dios en relación con el ser humano individual y 
colectivo, ya que desde el horizonte de la dimensión social de la Trinidad hay que puntualizar también la dimensión social del hombre. Si Dios es familia, el ser humano ha de entenderse dentro de la familia de los hombres, de la comunidad humana, porque precisamente el designio de Dios es el de "asociar a todos los hombres a la comunión trinitaria". Esto significa en concreto, en palabras de R. Berzosa que:

La imagen de Dios, en las personas, es no solo individual sino "corporativa", como Cuerpo, que es fuente de vida y amor recibidos. es la comunión humana en la comunión trinitaria [...] comunión de diferentes receptividades en el amor, pero comunión responsable de los demás, que rompe y elimina toda violencia, opresión, dependencia injusta, etc. (2010, p. 153).

Se abre entonces un largo camino de búsqueda de coherencia, de transparencia, de llevar a la práctica, y hasta las últimas consecuencias, lo que implica que la Trinidad sea el principio social del cristianismo:

La aportación de la simbólica de la Trinidad no es que Dios sea el Absoluto incondicionado, sino el eternamente autocondicionado a la vida, al amor, al bien, a la comunión [...] no se trata solamente de honrar a la Trinidad con fórmulas dogmáticas que preserven la ortodoxia perfecta de lo que afirmamos de Dios, sino, sobre todo, de imitar a Jesús, llevados por su espíritu, estableciendo entre los hombres unas relaciones que hagan de la sociedad una imagen verdadera de la comunión trinitaria (Vives, 1986, p. 42).

Si en el mundo y en nuestra sociedad existen la violencia, las desigualdades, las injusticias, la brecha entre ricos y pobres; si en la Iglesia existe el clericalismo, la lucha por el poder, la opulencia, la falta de comunión entre sus fieles; si las familias están destruidas por la infidelidad, el miedo al compromiso y el desamor; esto quiere decir que el mundo, la sociedad, la Iglesia, la familia, como comunidades humanas, no están siendo el reflejo auténtico de Dios-Trinidad.

Ser reflejo auténtico de Dios-Trinidad implica entonces ser imagen de la verdadera comunión trinitaria, que se percibe en las huellas del amor trinitario en el ser humano que ha sido creado para la comunión y el amor. 
Comunión trinitaria que se ha traducido en "una historia trinitaria, en el tiempo, que se comienza a narrar a través de gestos de solidaridad, reconciliación, libertad dada y recibida, pasión por la verdad y la justicia" (Berzosa, 2010, pp. 153-154).

Dios es experimentado como el padre de la misericordia que socorre a los más necesitados y que pide misericordia al hermano como expresión de la fe en Él. Recorramos ahora el ejemplo del pueblo de Israel y brevemente el de Jesús para descubrir que esta historia trinitaria ha ido de la mano de la búsqueda de la justicia y la fraternidad entre los hombres.

\section{Las leyes sociales del pueblo de Israel como fidelidad a la alianza con Yahvé}

Recordemos que el pueblo de Israel se organizó en estructuras sociales que daban cuenta del Dios que experimentaban, un Dios que les elegía como pueblo suyo. Convivencia humana, justicia y fraternidad eran los signos visibles de su fidelidad a la Alianza. Eran cada vez más pueblo de Dios, familia de Dios en cuanto se dejaban guiar por el designio divino.

G. von Rad (1996) enuncia una tesis interesante. Afirma que el llamado Código de la Alianza de Dt 12-26 en realidad eran leyes sociales centradas en un solo principio que se enuncia así: el pueblo de Dios, como figura social, política y religiosa de la monarquía, será una sociedad igualitaria que elimine la pobreza y la marginación.

Al comparar las legislaciones del Antiguo Oriente, von Rad observa que las leyes del pueblo de Israel son superiores en el aspecto social en relación con las de sus vecinos. Israel, por ejemplo, se preocupa de que todos sus ciudadanos sean iguales ante la ley, incluso el extranjero, el pobre y el esclavo deben gozar del beneficio de la ley. "El Código de la Alianza es eminentemente fraterno, no se comprende a sí mismo como una ley para la humanidad o como una ley natural, ni siquiera como una constitución civil de cualquier estado de derecho, sino como una ordenación comunitaria, como una regla de la comunidad" (1996, p. 219).

el Código, al presentar a Israel como "Pueblo de Dios" o "Pueblo de la Alianza" está significando que este pueblo es "familia de Dios". Esto 
conlleva un trato de hermandad con el hermano bajo el signo de la fraternidad y la justicia porque la misma legislación social está impregnada por un marcado interés social y moral. Las principales leyes contenidas en el Código y en algunos pasajes del libro del Éxodo así lo atestiguan: leyes acerca de la esclavitud (cf. Ex 21 y ss.; Dt 15), pago de los diezmos para ayuda de los desvalidos (cf. Dt 14, 28-29), límites del derecho a fianza (cf. Ex 22, 25-26; Dt 24, 6 y ss), ley sobre rebusca y espigueo, para ayudar al pobre (cf. Lv 19,9-10; Dt 24,21), deberes para con el pobre (cf. Lv 25,35), sobre el hurto en caso de necesidad (Dt 23,25-26) y prescripciones sobre el descanso sabático (cf. ex 23,12; Dt 5,14) (von Rad, 1976, pp. 283-301).

en concreto, para el pueblo de Israel la Alianza en el contexto de la historia de la salvación es la que daba sentido a todas las realidades socio-económicas. De esa misma ley de la Alianza nacía un proyecto de convivencia establecido bajo el signo de la fraternidad y la justicia, alentado por el amor de Dios a su pueblo.

Todos los programas sociales, desde la Ilustración hasta nuestros días, tratan del hombre, de su derecho a la felicidad y de sus justas pretensiones de participar en los bienes de esta vida. Pero la legislación veterotestamentaria no trata del hombre, sino de Dios. Si el pobre no debe ser objeto de explotación, si la sentencia no debe perjudicar al huérfano, etc., no es precisamente por la extraordinaria dignidad del hombre y por sus inalienables derechos, sino sencillamente, porque - como dice el libro del Deuteronomio- Dios ama a Israel (von Rad, 1996, p. 220).

Coda, en la misma línea que G. von Rad, al releer la historia del Antiguo Testamento, agrega que este Dios es un Dios liberador del hombre y promotor de la justicia, llevada hasta la comunión, en medio de los hombres. "este rostro de Dios de misericordia y fraternidad no puede ser invocado para justificar ningún orden político-social, sino que el amor trinitario entre los hombres es criterio de inspiración para que desde su luz, se señalen sus necesarias mediaciones estructurales" (Coda, 1993, p. 285).

El ejemplo de Israel que confiesa a Yahvé a través de relaciones fraternas y que experimenta a un Dios que ama al hombre, especialmente al marginado, nos ayuda a comprender la relación entre la fe y lo social y sus implicaciones en el campo de la justicia y la ética. es llamativo que Jesús, rostro revelador del Padre, no se sumara a ninguna de las corrientes del 
judaísmo de su época, sino que el anuncio que él hace se parece más al mensaje social del pueblo de Israel que promocionaba una sociedad igualitaria.

Jesús es el nuevo profeta que denuncia el alejamiento del verdadero rostro de Dios, su Padre. Sus acciones se sitúan en un marco ético-comunitario distinto al horizonte legalista y cultual judío. "Su movimiento se configura como un movimiento que busca la igualdad social y religiosa que se rige por el principio de misericordia, abierta no sólo a los elegidos (como se sentía el pueblo judío), sino a todos los seres humanos, con especial predilección por los pobres, como primeros destinatarios de su mensaje" (Castillo, 1992, pp. 60-61).

Tal mensaje es de carácter social y busca restablecer al ser humano de aquello que le impide ser plenamente hombre y mujer, opresiones e injusticias en nombre de Dios y del estado. Se enfrenta con la religión judía y su carácter ritual. Jesús arremete contra la pureza ritual, contra el Templo y la Ley porque no transparentaban al Dios de la misericordia.

Jesús contrasta visiblemente esta óptica cuando afirma, recordando al profeta Oseas 6,6; “Misericordia quiero y no sacrificios” (Mateo 9,13; 12,7), él se está refiriendo a que Dios prefiere la bondad hacia los demás y relativiza las prácticas cultuales que se realizaban en el Templo.

$\mathrm{Al}$ recordar estas palabras proféticas [las de Oseas], Jesús viene a decir que entre dos modos de relacionarse con Dios, uno con ritos, el otro mediante las relaciones humanas, Dios mismo prefiere el segundo, porque por encima de los ritos él quiere la misericordia para con los demás (Castillo, 1992, p. 62).

\section{La confesión de fe en Dios-Trinidad desde su dimensión social}

La confesión en Dios-Trinidad, teniendo en cuenta su dimensión social revelada en la historia, tiene incidencia en lo social, en la praxis cristiana, en la relación con la sociedad, ¿cómo sería una sociedad desde Dios-Trinidad? ¿Cómo sería la participación de los creyentes en la política, en las instituciones sociales? 
La fe en la Trinidad pone marcadamente de relieve una doble polaridad en el hombre: el hombre es, por una parte, un individuo dotado de libertad y, por otra, miembro de la comunidad humana, vinculado de múltiples maneras con los demás, y solo junto con ellos verdaderamente hombre. Ninguno de estos dos polos se puede escamotear, porque precisamente así, y solo así, se reproduce la esencia del Dios trino y se transforma en actividad humana (Greshake, 2002, p. 48).

e. Cambón (2000), en su libro La Trinidad modelo social, profundiza sobre las características típicas de un estilo de vida trinitario y propone el fundamento trinitario de algunos comportamientos sociales, relacionándolos con algunos aspectos de la vida trinitaria, partiendo de un interrogante central: ¿cuál es la importancia de vivir en los vínculos humanos y en todos los aspectos de la sociedad, el mismo tipo de relaciones que existen en Dios Trinidad?

La anterior pregunta es importante porque nos sitúa en el centro de nuestra reflexión: ¿qué le aporta el cristianismo a la sociedad desde su fe trinitaria? Le aporta la realidad humana y divina de la comunión, de la búsqueda de la fraternidad, la justicia-caridad y el impulso de valores seculares que son análogos a los del cristianismo, especialmente el concepto de solidaridad.

Nos parece equilibrada y realista la postura del teólogo J. Vives (1986), quien se pregunta si es la Trinidad un programa social. y responde que quizás la Trinidad no es exactamente un programa social, pero sí que se encuentran en ella las bases más sólidas para defender un nuevo concepto de hombre y de sociedad.

La Iglesia tendría que ser toda comunión y promotora de comunión en la sociedad, a imagen de la Trinidad. "este valor, el de la primacía de la comunión, debería ser la aportación específica que el cristianismo, por todos los medios posibles, tendría que hacer realidad en nuestro mundo tan destrozado por la violencia. Si no aportamos esto, somos sal insípida y luz que no alumbra" (Vives, 1986, p. 42).

en este sentido, el Concilio hizo un avance importante en la explicitación de las relaciones de la Iglesia con el mundo y la sociedad actual con fundamento en la comunicación de Dios en la historia y en la revelación de 
su designio salvífico, ya no de alejamiento, sino de cercanía y preocupación por los "gozos y las esperanzas de los hombres" (GS núm. 1).

Los números del 40 al 45 de GS precisan la función de la Iglesia en el mundo actual. Fijan la misión y el modo de estar de la Iglesia en el mundo, en la sociedad. Tal postura tiene su explicación en una visión distinta de Dios y su relación con el mundo, como lo afirmábamos anteriormente. GS 40 lo afirma categóricamente (haciendo alusión a ES 27): “cuanto hemos dicho sobre la dignidad de la persona humana, sobre la comunidad de los hombres, sobre el profundo significado de la humana actividad, constituye el fundamento de la relación entre la Iglesia y el mundo y la base de un mutuo diálogo".

Según S. Madrigal, la Iglesia que se percibe en GS es aquella que es sacramento de Dios, es decir, sacramento de cómo Dios está presente en el mundo. No es casual que estos números de GS lleven por subtítulo Relación mutua entre la Iglesia y el mundo. estos cinco números hacen de puente entre los fundamentos para dialogar con el mundo (1-39), cómo se comprende desde Dios la dignidad humana, la vida social, la actividad humana y algunos problemas más urgentes como el matrimonio y la familia, la difusión de la cultura, el orden económico y social, la vida política, la solidaridad internacional y la paz (46-93), que urgen ser iluminados por los fundamentos teológicos que el Concilio estima como imprescindibles (Madrigal, 2004 ).

La relación Iglesia-mundo que nos plantea a GS tiene detrás la relación Dios-mundo. Dios Trinidad ilumina la visión del hombre, del mundo, de la sociedad de la cual la Iglesia es depositaria:

La Iglesia, que procede del amor del Padre eterno, ha sido fundada en el tiempo por Jesucristo Redentor, y congregada en el espíritu Santo, tiene una finalidad salvífica y escatológica, que no se puede lograr plenamente, sino en el siglo futuro. Sin embargo, está ya presente en la tierra, formada por la reunión de hombres [...] que son llamados para formar en la historia del género humano la familia de los hijos de Dios (GS, núm. 40).

"esta perspectiva eclesiológica se apoya sobre el principio de la comunión de la familia de los hijos de Dios y en el desarrollo del designio universal y cósmico de la salvación" (Madrigal, 2004 , p. 6). GS (40-45) en definitiva, 
muestra el camino para integrar e iluminar a la sociedad humana con la familia de los hijos de Dios.

Gaudium et spes contempla con la mirada de fe la historia de la modernidad reciente. La convicción de fondo es la misma: un misterio permanente atraviesa el curso de la historia humana, a saber, que la ciudad de Dios se construye en la realidad presente. en este momento, el Concilio enumera aquellos beneficios que la Iglesia, al perseguir su finalidad salvífica, presta al mundo: la oferta de participación en la vida divina, la sanación y elevación de la dignidad de la persona humana, el afianzamiento de la sociedad humana, la dotación de un sentido y significado más profundo a la actividad y a la vida cotidianas. De esta manera - asevera el texto conciliar-, la Iglesia cree poder contribuir a "la humanización de la familia y de la historia humana" (Madrigal, 2004 , p. 8).

Recordemos que la fundamentación teológica de la moral socioeconómica y de la DSI a partir del Vaticano II es de profunda inspiración trinitaria y comunional, y se construye principalmente a partir del anterior esquema presentado por la constitución GS que busca dar una luz desde la fe a los problemas sociales y económicos del hombre actual y explicitar el proyecto de Dios para la humanidad (GS 24) (Galindo, 1996).

el CDSI es la iluminación práctica de las directrices que inspiró el Concilio y de la enseñanza social de la Iglesia que en palabras de León XIII no ha renunciado a decir la palabra que le corresponde acerca de las cuestiones de la vida social. La primera parte es de clara inspiración trinitaria, ya que es el amor trinitario (su designio de amor, capítulo I) el que le da sentido y razón de ser a la misión de la Iglesia y su doctrina social (capítulo II) y permite abogar por la persona humana y sus derechos (capítulo III) y fundamentar los principios sociales que construyan una sociedad más humana (capítulo IV).

La Iglesia, experta en humanidad, en una espera confiada y al mismo tiempo laboriosa, continúa mirando hacia los "nuevos cielos" y la "nueva tierra" (2 Pe 3,13), e indicándoselos a cada hombre, para ayudarle a vivir su vida en la dimensión del sentido auténtico. "Gloria Dei vivens homo": el hombre que vive en plenitud su dignidad da gloria a Dios, que se la ha donado (Martino, 2005, p. XXII). 
Detengámonos ahora a analizar cuál es la fuente en la que se inspira este amor social del que el cristiano es testigo en el mundo y qué entendemos cuando la Iglesia habla de la solidaridad y la compasión como rostros concretos de este amor social.

\section{La Trinidad como inspiradora de solidaridad y compasión en el mundo}

Partimos de que el agape de Dios Trinidad es el criterio de la orientación ética y de la praxis cristiana en la sociedad y en el ámbito político y económico (Coda, 1996). Una realidad que Pablo VI (1976), al culminar el año jubilar de 1975, recogía en la expresión profética "civilización del amor", es decir, una sociedad animada por el amor, "entendiendo por civilización ese conjunto de condiciones morales, civiles y económicas, que permiten a la vida humana una mejor posibilidad de existencia, una razonable plenitud, un feliz destino eterno".

este amor trinitario que inspira Dios entre los hombres es un amor solidario y compasivo, expresión del amor revelado en Cristo al mundo. Aquí basta recordar que el amor misericordioso en la Biblia se comprende a partir de la fidelidad de Dios a la alianza establecida con su pueblo y con el ser humano. La misericordia de Dios es fidelidad que se exterioriza con el perdón. Jesús es el rostro de la misericordia divina, de quien no abandonó al hombre a su suerte, sino que le envió su Hijo para que viéramos en él a la misericor- dia encarnada.

En esta reiterada promesa de misericordia, que se ha mantenido firme a lo largo de la historia, radica la auténtica riqueza de la humanidad. Pues la gracia y la misericordia de Dios en Jesucristo otorgan al mundo y a la vida humana unas nuevas normas: a la luz de ellas ya no se puede preguntarse por los méritos previos, pero tampoco por la gratuidad que cabría esperar de aquel que es objeto de la misericordia; la intensidad de la misericordia viene ahora exclusivamente determinada por la situación del otro, a quien hemos de dar testimonio de Cristo (Beyreuther, 1983, p.105). 
en el Antiguo Testamento, la misericordia (rahamim) significa ternura de entrañas, bondad de ser, piedad. en el Nuevo Testamento, el verbo eleo (sustantivo: eleos; adjetivo: eleemon) designa tanto la compasión, como la misericordia e introduce un aspecto doloroso del amor, hasta el punto de convertirlo en compasión. en el texto de Mateo de "Bienaventurados los misericordiosos, porque ellos alcanzarán misericordia" (Mt 5,7), "la misericordia no es puramente una cuestión de sentimiento referida solamente a personas de corazón sensible, afectadas por el dolor del otro. Por misericordia se designa a los actos concretos de compasión resultado de esos sentimientos: ser misericordioso equivale a practicar la misericordia" (López Melus, 2003, p.12).

Mateo usa el pasivo divino, utilizado por los judíos para no tener que pronunciar el nombre de Dios. en este caso equivale a decir que Dios será misericordioso con aquellos que lo hayan sido con los demás. esta bienaventuranza presenta una gran afinidad con la de la mansedumbre, ya que ambas forman parte del cortejo de virtudes de la caridad, que constituye la perfección cristiana y marchan indisolublemente unidas (cf. Col 3, 12-14) (López Melus, 2003, p. 356).

La misericordia se concibe entonces como compasión del corazón en relación con el prójimo, ella es formalmente la caridad. en otras palabras, la misericordia es la caridad hecha praxis concreta. Juan Pablo II en esta misma línea expresaba sobre la misericordia estas palabras iluminadoras:

El significado propio y verdadero de la misericordia no consiste solamente en una mirada, aunque sea la más penetrante y la más cargada de compasión, dirigida hacia el mal moral, corporal o material; la misericordia se manifiesta en su aspecto propio y verdadero cuando revaloriza, cuando promueve, cuando saca el bien de todas las formas del mal que existen en el mundo y en el hombre. Así entendida, constituye el contenido fundamental del mensaje mesiánico de Cristo y su fuerza constitutiva de su misión (1980).

Y lo hacía más explícito el Papa al afirmar que la misericordia es el rostro más auténtico del amor y la justicia. es decir, cuando en el Magisterio de la Iglesia se refiere a la solidaridad, lo está haciendo desde un amor compasivo 
hecho praxis social, que remueve las entrañas ${ }^{11}$. Amor compasivo que va más allá del concepto secular de solidaridad como "adhesión circunstancial a la causa o a la empresa de otros" (Real Academia de la Lengua española, 2001).

Pablo VI había subrayado la importancia de dialogar con la sociedad actual y hacer un anuncio explícito de la comunión solidaria de vida de las divinas Personas entre sí. en eS 27 presentaba a la Santísima Trinidad como un Misterio de diálogo:

La historia de la salvación narra precisamente este largo y variado diálogo que nace de Dios y teje con el hombre una admirable y múltiple conversación. es en esta conversación de Cristo entre los hombres donde Dios da a entender algo de Sí mismo, el misterio de su vida, unicísima en la esencia, trinitaria en las Personas, donde dice en definitiva cómo quiere ser conocido: Él es Amor [...] amor es nuestro mandamiento supremo [...] La Iglesia debe ir hacia el diálogo con el mundo en que le toca vivir. La Iglesia se hace palabra; la Iglesia se hace mensaje; la Iglesia se hace coloquio.

el papa Montini, colocando el acento en la vida de la comunión intratrinitaria y en su relación dialogal con los hombres como paradigma de lo que debe ser la vida de la Iglesia (en su realización como misterio de comunión interpersonal y como sacramento de salvación para el mundo), invitaba a los cristianos a dar testimonio de la doctrina del evangelio a la gran familia humana (eS 2).

Incluso, refiriéndose a los que no creen en Dios, pero que según Pablo VI están llenos de pasión y utopía, de sueños de justicia y de progreso, en busca de objetivos sociales divinizados, de ingenuo entusiasmo, de un recurso riguroso a la racionalidad humana, intentando ofrecer una concepción científica del universo, movidos a veces por nobles sentimientos, asqueados

11 Ver la explicación que presenta O. González de la expresión “entrañas de Dios y de Cristo", como una imagen para entender el rostro de Dios que es compasión y misericordia infinita. Tal imagen, según este autor, recorre la Escritura. En torno a la idea de la misericordia de Dios se establece la alianza. Asimismo, Lucas construye su cristología, teniendo como centro la ternura de Cristo (1997, pp. 43-48). 
de la mediocridad y del egoísmo de tantos ambientes sociales contemporáneos, son a veces más hábiles para sacar de nuestro evangelio formas y lenguaje de solidaridad y de compasión humana. ellos plantean una ética social humana y lanzan un reto importante a los cristianos, de llegar a ser capaces algún día de hacer que los que se dicen ateos vuelvan al manantial cristiano de donde brotan estas expresiones de valores morales (eS 38).

Por su parte Juan Pablo II, en continuidad con Pablo VI, propone el camino de la Santísima Trinidad en su acercamiento al hombre como programa para la Iglesia en su relación con el mundo, a través de su "Trilogía trinitaria" (Redemptor hominis, 4 de marzo de 1979, Dives in misericordia, 30 de noviembre de 1980 y Dominum et vivificantem, 18 de mayo de 1986). Sin embargo, es la encíclica Sollicitudo rei socialis del 30 de diciembre de 1987, al cumplirse el vigésimo aniversario de la Populorum Progressio de Pablo VI del 26 de marzo de 1967, la que entra en un estudio más teológico de la solidaridad, buscando en la "solidaridad" que reina en la comunidad original de la Santísima Trinidad la fundamentación teológica de lo que debe ser toda solidaridad dentro de la Iglesia y en relación con el mundo (Silanes, 1991).

el número 40 de SRS explica cómo entiende la Iglesia la solidaridad y cómo esta debe llegar a todos los hombres que comparten una dignidad común, fundamentada en la iconalidad divina, tanto individual como socialmente. Solidaridad que como dice el Papa es sin duda una virtud cristiana que tiene puntos de contactos con la caridad y que es signo distintivo de los discípulos de Cristo (Jn 13,35).

ese mismo número relaciona magistralmente la solidaridad con la Trinidad de la que es su fuente de esta manera:

A la luz de la fe, la solidaridad tiende a superarse a sí misma, al revestirse de las dimensiones específicamente cristianas de gratuidad total, perdón y reconciliación. entonces el prójimo no es solamente un ser humano con sus derechos y su igualdad fundamental con todos, sino que se convierte en la imagen viva de Dios Padre, rescatada por la sangre de Jesucristo y puesta bajo la acción permanente del espíritu Santo. Por tanto, debe ser amado, aunque sea enemigo, con el mismo amor con que le ama el Señor, y por él se debe estar dispuestos al sacrificio, incluso extremo: "dar la vida por los hermanos" (1 Jn 3,16). 
Y continua el número 40 de SRS afirmando que esta conciencia de Dios Trinidad, de un Padre común, de una hermandad de todos los hombres en Cristo y de la presencia y acción vivificadora del Espíritu Santo es la que nos confiere sobre el mundo y la sociedad un "nuevo criterio para interpretarlo". Y termina afirmando que a la luz de la fe trinitaria este es el modelo de unidad del género humano en el que se inspira la solidaridad en este caso cristiana: "este supremo modelo de unidad, reflejo de la vida íntima de Dios, Uno en tres Personas, es lo que los cristianos expresamos con la palabra 'comunión'".

encontramos entonces en el Magisterio social de la Iglesia, parafraseando a J. Moltmann ${ }^{12}$, que el Dios que presenta no es un Dios intramundano o extramundano, sino el Dios de la Misericordia. Misericordia que resumimos con las palabras de Juan Pablo II (1985):

Constituye el centro mismo de la revelación y de la alianza. La misericordia, tal como la explicó y practicó Jesús "rico en misericordia" es la cara más auténtica del amor, es la plenitud de la justicia. el amor de misericordia no es una mera compasión con el que sufre, sino una efectiva solidaridad con todos los afligidos.

este amor trinitario es el que inspira el amor social. Dios es ante todo Dios de ternura y por serlo es Dios de piedad, compasión y misericordia. Él mira en primer lugar a nuestro ser de hijos salidos de sus entrañas y fruto de su amor; en segundo lugar, se compadece de nuestra pobreza y tiene misericordia de nuestra debilidad; en tercer lugar, nos ofrece perdón por nuestros pecados. este es el orden, concluye O. González, en que hay que pensar a Dios como ternura, misericordia, compasión y perdón (1997).

Dios espera del hombre que haga misericordia; el recibirla es siempre una experiencia gratuita. Nunca es algo que pueda ser exigido por aquel que la espera. Toda misericordia humana, imperfecta, y toda falta de misericordia espera e implora, por tanto, ser colmada por la misericordia divina

12 La frase de este autor es: “el Dios de quien aquí se habla no es un Dios intramundano o extramundano, sino el 'Dios de la esperanza' (Rom 15,13)”, en Moltmann (1972, p. 19). 
y espera que ella se revele finalmente como un bien salvífico e imperecedero (Beyreuther, 1983, p. 106).

En definitiva, cuando la Iglesia anima al creyente a practicar la solidaridad en la sociedad, lo que le está diciendo es que ame como Dios ama al hombre, es decir, con amor misericordioso y compasivo, teniendo siempre presente que:

el actuar humano, cuando tiende a promover la dignidad y la vocación integral de la persona, la calidad de sus condiciones de existencia, el encuentro y la solidaridad de los pueblos y de las naciones, es conforme al designio de Dios, que no deja nunca de mostrar su Amor y su Providencia para con sus hijos (CDSI 35).

\section{Conclusiones}

Podemos resumir lo dicho en estas consideraciones:

a. el misterio trinitario de Dios manifestado por Jesucristo en el espíritu Santo es luz para comprender el misterio del hombre que se presenta como un ser creado para el amor y la comunión, a ejemplo del amor y la comunión intradivina.

b. De la anterior consideración se desprende que la verdad del hombre creado a imagen y semejanza de Dios es de gran envergadura. es la posibilidad real de que el hombre entre en contacto con Dios, en relación y profundo conocimiento, es decir, en comunión con él. Significa, además, el designio divino de que el hombre viva en comunión, en familia, con los demás, no en solitario, y se parezca más a Dios que es comunión.

c. en palabras de Benedicto XVI: "La historia de amor entre Dios y el hombre consiste en que la comunión de voluntad crece en la comunión del pensamiento y del sentimiento del hombre hacia Dios, de modo que nuestro querer y la voluntad de Dios coinciden cada vez más" (DCe 17).

d. Si Dios es amor, el hombre tiene una tarea importante: impregnar de amor toda comunidad en la que conviva empezando por la primera y fundamental que es la familia, y aquellas que están 
llamadas a ser familia: la Iglesia y la sociedad y, en definitiva, la familia humana.

e. Desde la consideración de la dimensión social de la Trinidad se vislumbra una misión concreta para el creyente: ser en el mundo testigo de la solidaridad y la compasión que Dios tiene con el hombre, precisamente porque la historia trinitaria ha sido la acción de Dios que busca y socorre al ser humano, especialmente al más necesitado al cual trata con misericordia infinita.

\section{Referencias}

Auer, J. (1982). Dios uno y trino. en J.-R. J. Auer, Curso de teología dogmática (vol. II). Barcelona: Herder.

Balthasar, H. U. (2004). Solo el amor es digno de fe. Salamanca: Sígueme.

Benedicto XVI (2005, 22 de mayo). Ángelus en la fiesta de la SS. Trinidad. L'Osservatore Romano.

Benedicto XVI. (2005). Deus caritas est. Roma: Librería editrice Vaticana.

Berzosa, R. (2010). La creación en clave trinitaria. Lumen, 5, 137-199.

Beyreuther, e. (1983). Diccionario teológico del Nuevo Testamento (vol. III). Salamanca: Sígueme.

Boff, L. (1987). La Trinidad, la sociedad y la liberación. Madrid: Paulinas.

Boff, L. (1990). La Santísima Trinidad es la mejor comunidad (5. a ed.). Madrid: Paulinas.

Cambón, e. (2000). La Trinidad como modelo social. Madrid: Ciudad Nueva.

Cantalamessa, R. (2005, 20 de mayo). Zenit. Recuperado de http://www.zenit.org/ article-15763?1=spanish

Castillo, J. M. (1992). Símbolos de libertad (5. a ed.). Salamanca: Sígueme.

CCe (1992). Catecismo de la Iglesia Católica. Catechismus Ecclesiae Catholicae. Roma.

Coda, P. (1993). Dios Uno y Trino. Revelación, experiencia y teología del Dios de los cristianos. Salamanca: Secretariado Trinitario.

Coda, P. (1996). El ágape como gracia y libertad. Madrid: Ciudad Nueva.

CTI (2004). Comunión y servicio: la persona humana creada a imagen de Dios. Roma: Librería editrice Vaticana.

CTI, C. T. (1981). Teología, cristología, antropología. Roma: Librería editrice Vaticana.

De Lubac, H. (1980). Meditación sobre la Iglesia. Madrid: encuentro. 
De Miguel, J. M. (2008). Trinidad divina y familia humana. Familia, 37, 39-60.

Del Cura, S. (2010). Afirmación radical del hombre: Dios trinitario y ateísmo contemporáneo. Semanas de Estudios Trinitarios, 44, 109-185.

Del Cura, S. (2010). Un solo Dios. Violencia exclusivista, pretensión de verdad y fe trinitaria en los recientes debates sobre el monoteísmo. Madrid: RADe.

Del Cura, S. (2006). Unus deus trinitas. Repensar el monoteísmo trinitario en diálogo con el judaísmo y con el islam. en Á.-S. J.-D. Cordovilla, Dios y el hombre en Cristo. Homenaje a Olegario González (pp. 245-271). Salamanca: Sígueme.

Forte, B. (1996). Trinidad como historia: ensayo sobre el Dios cristiano (2. ${ }^{a}$ ed.). Salamanca: Sígueme.

Galindo, Á. (1996). Moral socioeconómica. Madrid: BAC.

García Rojo, J. (2007). Si Dios es amor, ¿qué es el hombre? en J. R. Flecha, Dios es amor. Comentarios a la encíclica de Benedicto XVI, Deus Caritas est (pp. 123-150). Salamanca: Publicaciones Universidad Pontificia de Salamanca.

González de Cardedal, O. (1997). La entraña del cristianismo. Salamanca: Secretariado Trinitario.

Greshake, G. (2001). El Dios Uno y Trino. Una teología de la Trinidad. Barcelona: Herder.

Greshake, G. (2002). Creer en el Dios Uno y Trino: Una clave para entenderlo. Santander: Sal Terrae.

Hipona, S. A. De Trinitate.

Juan Pablo II (1980). Dives in misericordia, 5. Roma: editrice Vaticana.

Juan Pablo II (1985, 17 de febrero). Discurso a los jóvenes de Lima. en L'Osservatore Romano, 8-9.

Kasper, w. (1989). Teología e Iglesia. Barcelona: Herder.

Ladaria, L. (2002). La Trinidad misterio de comunión. Salamanca: Secretariado Trinitario.

López Melus, F. (2003). Las Bienaventuranzas. Eclosión de Amor. Madrid: edibesa.

Madrigal, S. (2004 ). Instituto Social León XIII. Recuperado de http://leonxiii.upsam. net/seminarios/04_seminario/02_sesion_02_santiago_madrigal.pdf

Martino, R. (2005). Presentación. en Compendio de la doctrina social de la Iglesia (pp. XV-XXIV). Madrid: BAC.

Moltmann, J. (1972). Teología de la Esperanza. Salamanca: Sígueme.

Moltmann, J. (1986). Trinidad y Reino de Dios: la doctrina sobre Dios (2. ${ }^{\mathrm{a}}$ ed.). Salamanca: Sígueme.

Pablo VI (1976, 4 de enero). Audiencia General (31 de diciembre de 1975). L'Osservatore Romano. 
Pikaza, X. (2005). Enchiridion Trinitatis. Textos básicos sobre el Dios de los cristianos. Salamanca: Secretariado Trinitario.

Rahner, K. (1969). el Dios-Trino como principio y fundamento trascendente de la historia de salvación. en J.-L. M. Feiner, Mysterium Salutis (vol. II, pp. 360-446). Madrid: Cristiandad.

Real Academia de la Lengua española (2001). Diccionario de la Real Academia Española (22. ${ }^{\text {a }}$ ed.). Madrid: RAe.

Ruiz de la Peña, J. L. (1988). Imagen de Dios. Antropología teológica fundamental (4. ${ }^{\text {a ed.). }}$ Santander: Sal Terrae.

Silanes, N. (1991). La Santísima Trinidad, programa social del cristianismo. Principios bíblico-teológicos. Salamanca: Secretariado Trinitario.

Silanes, N. (1995). Presentación a las ponencias del XXIX Simposio de Teología Trinitaria. en X. S. Trinitaria, Misterio trinitario y familia humana (pp. 9-12). Salamanca: Secretariado Trinitario.

Spicq, C. (1977). El agape en el Nuevo Testamento. Salamanca: Ceres.

Uríbarri, G. (1996). Monarquía y Trinidad. Madrid: Estudios 62, Universidad Pontificia de Comillas.

Vásquez, J. M. (2008). Trinidad y sociedad. Implicaciones éticas y sociales en el pensamiento de Leonardo Boff. Salamanca: Secretariado Trinitario.

Velasco, J. M. (2007). El encuentro con Dios (3. ${ }^{\mathrm{a}} \mathrm{ed}$.). Madrid: Caparrós editores.

Vives, J. (1986). Creer el credo. Santander: Sal Terrae.

Von Rad, G. (1976). Estudios sobre el Antiguo Testamento. Salamanca: Sígueme.

Von Rad, G. (1996). La acción de Dios en Israel: Ensayos sobre el Antiguo Testamento. Madrid: Trotta.

winninger, P. (1967). El libro de la familia. Madrid: PPC 
